\title{
Intradermal Vaccination: A Potential Tool in the Battle Against the COVID-19 Pandemic?
}

\author{
Alberto Migliore $\mathbb{I D}^{\prime}$ \\ Gianfranco Gigliucci $\mathbb{D}^{\prime}$ \\ Raffaele Di Marzo ${ }^{2}$ \\ Domenico Russo ${ }^{3}$ \\ Massimo Mammucari (iD) 4 \\ 'Department of Internal Medicine, Unit \\ of Rheumatology, San Pietro \\ Fatebenefratelli Hospital, Rome, Italy; \\ ${ }^{2}$ Italian Society of Mesotherapy, Rome, \\ Italy; "'San Marco" Hospice and Palliative \\ Care, Latina, Italy; ${ }^{4}$ Primary Care Unit \\ ASL RM I, Rome, Italy
}

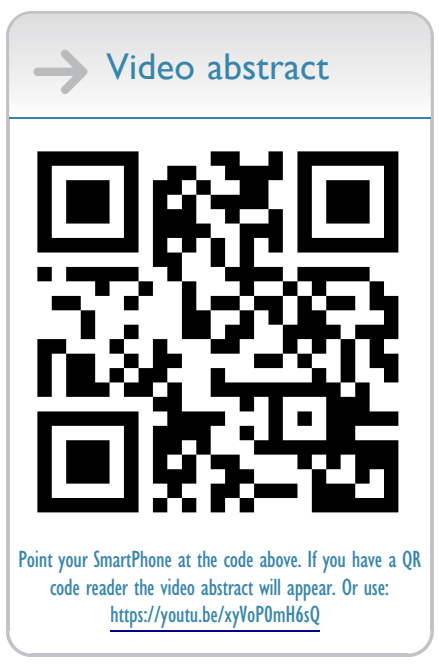

Correspondence: Alberto Migliore Email migliore.alberto60@gmail.com

\begin{abstract}
This narrative review is the final output of an initiative of the SIM (Italian Society of Mesotherapy). A narrative review of scientific literature on the efficacy of fractional intradermal vaccination in comparison with full doses has been conducted for the following pathogens: influenza virus, rabies virus, poliovirus (PV), hepatitis B virus (HBV), hepatitis A virus (HAV), diphtheria-tetanus-pertussis bacterias (DTP), human papillomavirus (HPV), Japanese encephalitis virus (JE), meningococcus, varicella zoster virus (VZV) and yellow fever virus. The findings suggest that the use of the intradermal route represents a valid strategy in terms of efficacy and efficiency for influenza, rabies and HBV vaccines. Some systematic reviews on influenza vaccines suggest the absence of a substantial difference between immunogenicity induced by a fractional ID dose of up to $20 \%$ and the IM dose in healthy adults, elderly, immunocompromised patients and children. Clinical studies of remaining vaccines against other pathogens (HAV, DTP bacterias, JE, meningococcal disease, VZV, and yellow fever virus) are scarce, but promising. In the context of a COVID-19 vaccine shortage, countries should investigate if a fractional dosing scheme may help to save doses and achieve herd immunity quickly. SIM urges the scientific community and health authorities to investigate the potentiality of fractionate intradermal administration in antiCOVID-19 vaccination.
\end{abstract}

Keywords: vaccination, intradermal, COVID-19, dose sparing

\section{Introduction}

The efficacy of administration of an oral (OS), intramuscular (IM), intradermal (ID), subcutaneous (SC), intranasal (IN), and intraperitoneal (IP) vaccine depends on the immunogenic activity of the antigens. Most viruses infect the body via the respiratory/digestive/genital tract so a mucosal vaccine can play an important role in generating the immunogenic response at the site where the infection occurred. However, it is difficult to determine which is the most effective route of administration of a vaccine and which is the best adjuvant to achieve the greatest immunogenicity. In fact, the biological activity, the antigen-adjuvant interaction, the selection, the mechanism of action, the formulation, the dosage and the physicalchemical parameters of the adjuvant are parameters of difficult evaluation. ${ }^{1}$ Vaccination was recently launched to combat the COVID-19 pandemic. At the same time, the recommendations of the Italian Society of Mesotherapy (SIM) were published, suggesting that the intradermal route offers potential dose-sparing compared to the intramuscular route. We therefore briefly discussed the evidence of the intradermal route in the field of vaccination. 


\section{Evidence from the Literature}

In recent years, vaccination against influenza viruses also represents a fundamental challenge in the social health sector, and the search for the most suitable formulations, methods of administration and mechanisms of action are the subject of debate. The skin is an excellent target for the administration of vaccines, both for its easy accessibility and for its ability to induce a humoral and cellular immune response. Vaccination can be epidermal (ED), ID or SC. The epidermis is the first and most formidable barrier against exposure to foreign substances and pathogens, and welcomes keratinocytes, fundamental cells of both structural and immune types, and cytokines. ${ }^{2-6}$

The dermis comprises two layers: the more superficial papillary dermis and the deeper reticular dermis. The papillary dermis $(100-300 \mu \mathrm{m})$ is the target layer for ID immunization and is rich in antigen presenting cells (APC), such as dermal dendritic cells (DDCs). It is rich in fibroblasts, a network of elastin and collagen fibers, lymphatic and blood vessels, dendritic cells, macrophages and T cells. Dendritic cells are distributed in the epidermis and in the dermis, in particular around its vascularized areas. $^{7}$

DDCs capture antigens deposited in the dermis and migrate to regional lymph nodes, where the antigens are presented to $\mathrm{T}$ lymphocytes. Soluble antigens also migrate to lymph nodes, resulting in activation of B lymphocytes. ${ }^{4,5}$ Due to the abundance of APCs in the dermis, ID administration of reduced antigenic doses (most often $20 \%$ or $30 \%$ of the standard amount of antigen), can induce immune responses equivalent to standard doses administered IM or SC. ${ }^{3,6}$ Therefore, doses of vaccine smaller $(1 / 10$ or $1 / 5)$ than a dose administered by the $\mathrm{SC}$ or IM route can be used.

The hypodermic layer, made up of adipose tissue with the functions of insulator and reservoir of the interstitial fluid, allows a free diffusion of cytokines and immune cells. ${ }^{7,8}$ Keratinocytes, Langerhans cells, mast cells, dendritic cells and macrophages play an essential role from the immune point of view by storing and inducing the production of peptides, chemotactic proteins and cytokines. $^{9,10}$

In particular, keratinocytes participate in skin immune responses by producing large quantities of interleukin-1 $\alpha$ (IL- $1 \alpha$ ), tumor necrosis factor (TNF) and $\beta$-defensin in response to various stimuli (kinetic and thermal trauma, exposure to ultraviolet radiation, cytokines and neuropeptides). IL-1 $\alpha$ and IL-1 $\beta$ are produced by Langerhans cells and act as potent stimulators of local immune function with a large number of chemokines released by the same keratinocytes and other immunoregulatory cytokines. These products have various important effects on skin-resident immune cells, such as mast cells, dendritic cells and macrophages, resulting in upregulation of the expression of other immune mediators and additional blood immune cells. However, the induction of local inflammation through IL-1 depends on a delicate balance between agonists (IL-1 $\alpha$, IL-1 $\beta$, caspase-1 and the IL-1 receptor $1 \mathrm{IL}-1 \mathrm{R} 1$ ) and antagonists (IL-1Ra and IL-1R2), and each of these molecules can be produced by keratinocytes under various conditions, as well as by other skin cells. $^{10-12}$

After this first phase of immune activation (innate immunity), the activation of $\mathrm{T}$ and $\mathrm{B}$ lymphocyte cells (acquired immunity) follows. The exposure of antigens by APC cells, including Langerhans cells, in fact determines the activation of $\mathrm{T}$ lymphocytes through the interaction with their receptor ( $\mathrm{T}$ cell receptor - TCR), with the maturation of naive cells in effector cells which aim to amplify the immune response and also activate B lymphocytes. ${ }^{8,13}$ Given the different immune cells, their organization in the different layers of the skin and the variety of immune responses, may we consider the skin as a target organ for immunization. ${ }^{7}$

Many studies have evaluated ID vaccination versus IM or SC vaccination (Table 1). Clinical trials have evaluated influenza vaccines, hepatitis B vaccines, polio, rabies, and yellow fever. ${ }^{14}$ In fact, it has been known for some years that the ID vaccine can improve the immune response. ${ }^{15}$ In addition, ID vaccines (eg influenza) with a lower dose than IM formulations have been reported to induce effective immunogenic responses. ${ }^{16}$ Indeed, thanks to dermal APCs that induce a strong adaptation of the immune response, vaccine doses fractioned $1 / 10$ or $1 / 5$ with respect to an SC dose or an IM dose can be used to induce immunization. ${ }^{3,6}$ These advantages represent a strong point and could be useful during periods of shortage of vaccines or in case of increased demand due to the presence of a pandemic.

In 2013 Joon Young Song and collaborators found that the ID administration of one fifth of the dose of influenza vaccine (usually administered IM) elicited comparable antibody responses 1 month after vaccination meeting the EMA criteria. $^{17}$

In 2018 Ivan FN Hung and collaborators reported similar conclusions analyzing an anti-influenza vaccine, 
Table I Trial Reporting Comparison Between IM and ID Route of Vaccination

\begin{tabular}{|c|c|c|c|c|c|}
\hline Reference & Disease & Vaccine Type & Population & Comparative Doses/Doses & Results \\
\hline Song $2013^{17}$ & Influenza & $\begin{array}{l}\text { Trivalent } \\
\text { inactivated } \\
\text { split vaccine }\end{array}$ & $\begin{array}{l}96 \text { healthy } \\
\text { young } \\
\text { adults }\end{array}$ & $\begin{array}{l}\text { - intramuscular full-dose } 15 \mu \mathrm{g} \\
\text { - intradermal one-half dose } \\
7.5 \mu \mathrm{g} ; \\
\text { - intradermal one-fifth dose } \\
3 \mu \mathrm{g} ;\end{array}$ & $\begin{array}{l}\text { ID administration of a one-fifth dose of influenza } \\
\text { vaccine elicited antibody responses comparable to } \\
\text { the ID one-half dose and a conventional IM } \\
\text { vaccination at I month post-vaccination. }\end{array}$ \\
\hline $\begin{array}{l}\text { Resik } \\
2010^{20}\end{array}$ & Polio & $\begin{array}{l}\text { Inactivated } \\
\text { poliovirus } \\
\text { vaccine }\end{array}$ & 364 Infants & $\begin{array}{l}\text { - intramuscular full dose } \\
0.5 \mathrm{~mL} \\
\text { - intradermal one-fifth dose } \\
0.1 \mathrm{~mL}\end{array}$ & $\begin{array}{l}\text { Seroconversion with fractional IPV was 19\% higher } \\
\text { than the full dose }\end{array}$ \\
\hline $\begin{array}{l}\text { Anand } \\
2015^{21}\end{array}$ & Polio & $\begin{array}{l}\text { Inactivated } \\
\text { poliovirus } \\
\text { vaccine } \\
\text { Oral poliovirus } \\
\text { vaccine }\end{array}$ & 922 Infants & $\begin{array}{l}\text { - intramuscular full dose } \\
0.5 \mathrm{~mL} \\
\text { - intradermal one-fifth dose } \\
0.1 \mathrm{~mL} \\
\text { - oral dose }\end{array}$ & $\begin{array}{l}\text { Seroconversion with fractional IPV at was } 43 \% \\
\text { higher than IPV full dose }\end{array}$ \\
\hline $\begin{array}{l}\text { Mohammed } \\
2010^{22}\end{array}$ & Polio & $\begin{array}{l}\text { Inactivated } \\
\text { poliovirus } \\
\text { vaccine }\end{array}$ & 373 Infants & $\begin{array}{l}\text { - intramuscular full dose } \\
0.5 \mathrm{~mL} \\
\text { - intradermal pne-fifth dose } \\
0.1 \mathrm{~mL}\end{array}$ & $\begin{array}{l}\text { Seroconversion with fractional IPV was } 40 \% \text { higher } \\
\text { than IPV ful dose }\end{array}$ \\
\hline $\begin{array}{l}\text { Resik } \\
2013^{23}\end{array}$ & Polio & $\begin{array}{l}\text { Inactivated } \\
\text { poliovirus } \\
\text { vaccine }\end{array}$ & 310 Infants & $\begin{array}{l}\text { - intramuscular full dose } \\
0.5 \mathrm{~mL} \\
\text { - intradermal one-fifth dose } \\
0.1 \mathrm{~mL}\end{array}$ & $\begin{array}{l}\text { Seroconversion with fractional IPV was } 35 \% \text { higher } \\
\text { than IPV full dose }\end{array}$ \\
\hline
\end{tabular}

Abbreviations: IPV, inactivated poliovirus vaccine; IM, intramuscular; ID, intradermal.

reporting levels of immunogenicity and efficacy not lower thanks to a dose of $3 \mu \mathrm{g}$ or $9 \mu \mathrm{g}$ administered by ID route, compared to the full dose of $15 \mu \mathrm{g}$ administered for IM regardless of age. ${ }^{18}$ Recently Hettinga and coll. concluded that ID administration of vaccine at lower doses than the IM route may represent a valid alternative both in terms of safety and efficacy. ${ }^{7}$

A recent study reported the results of several trials related to the inactivated poliovirus vaccine (IPV). ${ }^{19}$ Four studies compared two doses of $0.1 \mathrm{~mL}$ fractionated IPV (f-IPV fractional dose IPV) administered by ID with the full dose of $0.5 \mathrm{~mL}$ vaccine IM. Two further studies evaluated the immunogenicity of two doses of vaccine fractionated by ID without comparison with a full dose of IPV IM, and three further studies evaluated the immunogenicity of IPV administered at the full dose. The results of the antibody curves 4 weeks after the administration of a full dose of IPV compared with two divided doses, showed that the latter resulted in a higher antibody titer than the single full dose. Another study conducted in Cuba showed that seroconversion with fractional IPV at 6 and 10 weeks was $19 \%$ higher than the full dose after 6 weeks $(55 \%$ vs $36 \% ; \mathrm{p}<0.001)$, with a relative increase of $53 \%{ }^{20}$ Median antibody titers were 2-fold higher with two doses of f-IPV compared with one dose of IPV. In Bangladesh, type 2 seroconversion with f-IPV at 6 and 14 weeks was $43 \%$ higher than IPV at 6 weeks $(81 \%$ vs $38 \%$; $\mathrm{p}<0.001$ ), with a relative increase of $113 \%{ }^{21}$ The median antibody titers after two doses of f-IPV were 16 times higher than one dose of IPV. Overall, $78 \%$ of participants seroconverted or started seroconversion after one dose of f-IPV. In Oman, seroconversion with f-IPV at 2 and 4 months was $40 \%$ higher than IPV at 2 months ( $72 \%$ vs $32 \% ; \mathrm{p}<0.001$ ), with a relative increase of $125 \% .^{22}$ The median antibody titer was 5 times higher with two doses of f-IPV than with one dose of IPV. In another study conducted in Cuba, seroconversion with f-IPV at 4 and 8 months was $35 \%$ higher than IPV at 4 months $(98 \%$ vs $63 \% ; p<0.001$ ), with a relative increase of $56 \% .{ }^{23}$ Median antibody titers were 32 times higher after two doses of f-IPV compared with one dose of IPV. After a 4-month f-IPV dose, $97 \%$ of participants had serum converted or 
had initiated seroconversion. Overall, two doses of f-IPV induced higher seroconversion (median absolute increase: $37 \%$, range: $19-42 \%$; median relative increase: $84 \%$, range: 53-125\%) and higher antibody titers (median: 10 times; range: 2-32 times) compared to a full IPV dose given as a single solution. Three studies reported $69-80 \%$ seroconversion after a full dose of IPV at 14 weeks with median titers of 18-36. ${ }^{24-26}$

In April 2016, in light of the global shortage of IPV, the strategic advisory group of experts on immunization (SAGE) recommended considering a two-dose $(0.1 \mathrm{~mL}$ each) IPV schedule at 6 and 14 weeks instead of a full dose $(0.5 \mathrm{~mL})$ at 14 weeks. ${ }^{27}$ The WHO Position Paper on Polio states that in the context of an IPV shortage, countries may consider establishing a fractional 2-dose dosing scheme that could ensure that all eligible children receive IPV, saving dose and producing results of better immunogenicity than a single full dose of IPV.

Data presented in this article are the basis of the recommendation of two doses of f-IPV at 6 and 14 weeks as an alternative to full dose IPV at 14 weeks in addition to bivalent oral poliovirus vaccine (BOPV) at 6 , 10 and 14 weeks. Two doses of f-IPV, 4 weeks to 4 months apart are more immunogenic for type 2 poliovirus than one dose of IPV administered at the time of the first dose ID.

A recent review of the rabies vaccine ${ }^{28}$ reported 338 publications in the period between 1997 and 2018, 40 of which were evaluated for immunogenicity, and 371 publications in the period between 2007 and 2018 of which 13 publications evaluated. The immunogenicity of rabies vaccines was analyzed according to 3 criteria: proportion of subjects reaching the antibody threshold of $0.5 \mathrm{IU} \mathrm{mL}$ after ID vaccination, relationship between potency and immunogenicity of the vaccine administered by ID route and comparison of antibody responses after vaccination IM or ID. Overall, vaccines administered via the ID route were adequately immunogenic, and post-exposure prophylaxis by ID route was equally immunogenic like the IM route. On the other hand, pre-exposure prophylaxis by ID administration tended towards lower antibody titers compared to vaccination by IM (data not associated with clinical relevance). Regarding efficacy, the vaccine was evaluated by examining the survival of patients after confirmed exposure to the virus, and data from over 30,000 subjects who performed post-exposure rabies prophylaxis showed no deficiency in terms of efficacy of current vaccines administered by ID administration.
Two recent systematic reviews, comparing the immunogenicity and safety of the influenza ID vaccine at reduced doses with full IM doses, confirmed the immunogenicity of the Influenza ID vaccine and the potential offered by the dose-sparing effect of the ID route as a suitable alternative to standard dose of intramuscular vaccine and to full intramuscular dose during vaccine shortages, ${ }^{29}$ and in terms of costs compared to standard routes of administration. ${ }^{2}$ The results of the studies identified on influenza vaccines reported in this systematic review suggest the absence of a substantial difference between immunogenicity induced by a fractional ID dose of up to $20 \%$ and the IM dose in healthy adults, elderly, immunocompromised patients and children.

These results are consistent with the results of previous systematic reviews and meta-analyses of influenza vaccines in these patient groups ${ }^{30-32}$ (Table 2).

For rabies vaccines, antibody responses after immunization via fractional ID vaccine (10-20\%) were equivalent to IM or SC administration in 29 of 33 studies. However, a dose meta-analysis of booster vaccine including 4912 subjects revealed lower antibody levels after primary ID administration compared to IM immunization. ${ }^{33}$ However, it should be noted that this review evaluated antibody responses 1-2 years after primary (pre-booster) immunization programs; while in other analyses, immunogenicity was evaluated after 4 weeks from primary immunization.

With regard to vaccines against hepatitis B virus (HBV - hepatitis B virus), administered with ID doses of 10-20\% compared to the standard IM dose, variable results were highlighted. A meta-analysis found that ID doses of 1-2 $\mu \mathrm{g}$ were found to have lower immunization than IM administration, while conversely, ID doses $>2 \mu \mathrm{g}$ were equally effective. ${ }^{2}$ Another meta-analysis ${ }^{34}$ involving immunocompetent subjects demonstrated that ID immunization by HBV vaccine was slightly lower $(14 \%)$ than serum protection induced by IM administration. However, this meta-analysis did not evaluate a stratification of the data according to the dose ID used. In special categories of patients, such as hemodialysis or chronic kidney disease patients, some studies have compared serum protection rates in patients treated by ID with high fractional dose of HBV vaccine versus patients treated by IM. The results showed equivalence of the immunization level. ${ }^{35,36}$

The authors concluded that HBV ID vaccines, despite a lower vaccine dose, induce higher seroprotection than the IM route upon completion of the regular vaccine 
Table 2 Review and Meta-Analysis Reporting Comparison Between IM and ID Route of Vaccination

\begin{tabular}{|c|c|c|c|c|c|}
\hline Reference & Disease & $\begin{array}{l}\text { Type of } \\
\text { Article }\end{array}$ & $\begin{array}{l}\text { N. of } \\
\text { Studies }\end{array}$ & $\begin{array}{l}\text { Comparative Doses/ } \\
\text { Doses }\end{array}$ & Results \\
\hline $\begin{array}{l}\text { Young } \\
2011^{16}\end{array}$ & Influenza & Review & 13 & $\begin{array}{l}\text { - intramuscular full-dose } \\
\text { I5 } \mu \mathrm{g} \\
\text { - intradermal } 3 / 5-2 / 5- \\
\text { one-fifth dose } 9-6-3 \mu \mathrm{g}\end{array}$ & $\begin{array}{l}\text { Comparable efficacy between ID and IM } \\
\text { administration of influenza vaccine in the } 18-60 \text {-year } \\
\text { old population, and comparable or superior efficacy } \\
\text { of ID vaccinations compared with IM administration } \\
\text { in }>60 \text { year old population. }\end{array}$ \\
\hline $\begin{array}{l}\text { Hung } \\
2018^{18}\end{array}$ & Influenza & Review & $\begin{array}{l}\text { Considered } \\
\text { in our article } \\
4 \\
\text { Meta-analysis }\end{array}$ & $\begin{array}{l}\text { - intramuscular full-dose } \\
15 \mu \mathrm{g} \\
\text { - intradermal 3/5- one-fifth } \\
\text { dose } 9-3 \mu \mathrm{g}\end{array}$ & $\begin{array}{l}\text { Four meta-analysis suggested a non-inferior } \\
\text { immunogenicity and efficacy with the reduced dose } \\
3 \mathrm{mg} \text { or } 9 \mathrm{mg} \text { ID vaccination, when compared with } \\
\text { the full-dose I5 } \mathrm{mg} \text { IM influenza vaccination } \\
\text { regardless of age. }\end{array}$ \\
\hline $\begin{array}{l}\text { Hettinga } \\
2020^{7}\end{array}$ & $\begin{array}{l}\text { Influenza } \\
\text { (and } \\
\text { other } \\
\text { disease) }\end{array}$ & Review & 1 & I & $\begin{array}{l}\text { ID administration of vaccine at lower doses than the } \\
\text { IM route may represent a valid alternative both in } \\
\text { terms of safety and efficacy }\end{array}$ \\
\hline $\begin{array}{l}\text { Anand } \\
2017^{19}\end{array}$ & Polio & Review & 9 & $\begin{array}{l}\text { - intramuscular full dose } \\
0.5 \mathrm{~mL} \\
\text { - intradermal one fifth } \\
\text { dose } 0.1 \mathrm{~mL}\end{array}$ & $\begin{array}{l}\text { ID administration of a fractionate dose showed } \\
\text { better immunization than the IM dose }\end{array}$ \\
\hline $\begin{array}{l}\text { Denis } \\
2019^{28}\end{array}$ & Rabies & Review & $\begin{array}{l}4 \mathrm{I}(\mathrm{I} 3 \\
\text { comparison } \\
\text { ID/IM route })\end{array}$ & $\begin{array}{l}\text { - intramuscular full dose } \\
\text { I- } 0.5 \mathrm{~mL} \\
\text { - intradermal } 3 / 5-2 / 5 \text { - } \\
\text { one-fifth - one tenth dose }\end{array}$ & $\begin{array}{l}\text { ID route were adequately immunogenic and post- } \\
\text { exposure prophylaxis by ID route was equally } \\
\text { immunogenic than by IM route. Pre-exposure } \\
\text { prophylaxis by ID administration tended towards } \\
\text { lower antibody titers compared to vaccination by IM } \\
\text { (data not associated with clinical relevance) }\end{array}$ \\
\hline $\begin{array}{l}\text { Egunsola } \\
2021^{29}\end{array}$ & Influenza & $\begin{array}{l}\text { Review and } \\
\text { Meta-analysis } \\
\text { (random effects } \\
\text { model) }\end{array}$ & $\begin{array}{l}30 \text { for } \\
\text { Review and } \\
\text { Meta-analasys }\end{array}$ & $\begin{array}{l}\text { - intramuscular full dose } \\
\text { I5 } \mu \mathrm{g} \\
\text { - intradermal reduce dose } \\
\text { 15-9-7.5-6-5-4-3 } \mu \mathrm{g}\end{array}$ & $\begin{array}{l}\text { Similarity in immunogenicity was found between the } \\
\text { reduced dose ID and full dose IM influenza vaccine. } \\
\text { Low-dose ID vaccine could be a reasonable } \\
\text { alternative to standard-dose IM vaccination. }\end{array}$ \\
\hline $\begin{array}{l}\text { Schnyder } \\
2020^{2}\end{array}$ & $\begin{array}{l}\text { Influenza } \\
\text { (and } \\
\text { other } \\
\text { diseases) }\end{array}$ & $\begin{array}{l}\text { Review and } \\
\text { Meta-analysis } \\
\text { (fixed effects } \\
\text { model) }\end{array}$ & $\begin{array}{l}19 \text { Review } \\
22 \\
\text { Meta-analysis }\end{array}$ & $\begin{array}{l}\text { - intramuscular full dose } \\
15 \mu \mathrm{g} \\
\text { - intradermal varying } \\
\text { between } 3 / 5 \text { - one-fifth } \\
\text { dose } 9-3 \mu \mathrm{g}\end{array}$ & $\begin{array}{l}\text { Comparing ID and IM immunization similar antibody } \\
\text { responses were reported. }\end{array}$ \\
\hline $\begin{array}{l}\text { Marra } \\
2013^{30}\end{array}$ & Influenza & $\begin{array}{l}\text { Meta-analysis } \\
\text { (random effect } \\
\text { model) }\end{array}$ & 13 & $\begin{array}{l}\text { - intramuscular full dose } \\
15 \mu \mathrm{g} \\
\text { - intradermal I5 } \mu \mathrm{g}, 3 / 5- \\
2 / 5 \text { - one-fifth dose } 9-6-3 \\
\mu \mathrm{g}\end{array}$ & $\begin{array}{l}\text { No significant difference in immunologic response } \\
\text { was found comparing ID with IM administration in } \\
\text { the overall population. Higher doses of ID vaccine in } \\
\text { the older adult population produced a better } \\
\text { response. }\end{array}$ \\
\hline $\begin{array}{l}\text { Pileggi } \\
2015^{31}\end{array}$ & Influenza & $\begin{array}{l}\text { Meta-analysis } \\
\text { (random and } \\
\text { fixed effect } \\
\text { model) }\end{array}$ & 14 & $\begin{array}{l}\text { - intramuscular full dose } \\
\text { I5 } \mu \mathrm{g} \\
\text { - intradermal I5 } \mu \mathrm{g}, 3 / 5-2 / \\
5 \text { dose } 9-6 \mu \mathrm{g}\end{array}$ & $\begin{array}{l}\text { Seroprotection with ID route resulted comparable } \\
\text { to IM in elderly patients }\end{array}$ \\
\hline
\end{tabular}

(Continued) 
Table 2 (Continued).

\begin{tabular}{|c|c|c|c|c|c|}
\hline Reference & Disease & $\begin{array}{l}\text { Type of } \\
\text { Article }\end{array}$ & $\begin{array}{l}\text { N. of } \\
\text { Studies }\end{array}$ & $\begin{array}{l}\text { Comparative Doses/ } \\
\text { Doses }\end{array}$ & Results \\
\hline $\begin{array}{l}\text { Pileggi } \\
2015^{32}\end{array}$ & Influenza & $\begin{array}{l}\text { Meta-analysis } \\
\text { (random and } \\
\text { fixed effect } \\
\text { model) }\end{array}$ & 6 & $\begin{array}{l}\text { - intramuscular full dose } \\
\text { I5 } 5 \mathrm{~g} \\
\text { - intradermal } 7.5 \mu \mathrm{g}, 3 / 5-2 / \\
\text { 5- one-fifth dose } 9-6-3 \mu \mathrm{g}\end{array}$ & $\begin{array}{l}\text { The seroprotection rate induced by the ID vaccine } \\
\text { is comparable to that elicited by the IM vaccine in } \\
\text { immunocompromized patients }\end{array}$ \\
\hline $\begin{array}{l}\text { Langedijk } \\
2018^{33}\end{array}$ & Rabies & $\begin{array}{l}\text { Review and } \\
\text { Meta-analysis } \\
\text { (random effects } \\
\text { model) }\end{array}$ & $\begin{array}{l}36 \text { Review } \\
19 \\
\text { Meta-analysis }\end{array}$ & $\begin{array}{l}\text { - intramuscular full dose } \\
\mathrm{I}-0.5 \mathrm{~mL} \\
\text { - intradermal } 2 / 5-\mathrm{I} / 5 \text { - one } \\
\text { tenth dose }\end{array}$ & $\begin{array}{l}\text { Reduced antibody levels were found after ID } \\
\text { primary schedules compared to IM schedules. } \\
\text { Responses after booster immunization were } \\
\text { adequate for both routes. }\end{array}$ \\
\hline $\begin{array}{l}\text { Schnyder } \\
2020^{2}\end{array}$ & $\begin{array}{l}\text { Hepatitis } \\
\text { B (and } \\
\text { other } \\
\text { diseases) }\end{array}$ & $\begin{array}{l}\text { Review and } \\
\text { Meta-analysis } \\
\text { (fixed effects } \\
\text { model) }\end{array}$ & $\begin{array}{l}\text { 4I Review } \\
\text { I5 } \\
\text { Meta-analysis }\end{array}$ & $\begin{array}{l}\text { - intramuscular full dose } \\
20-10 \mu \mathrm{g} \text { (on } \\
\text { haemodialysis patients up } \\
\text { to } 40 \mu \mathrm{g} \text { ) } \\
\text { - intradermal one-tenth } \\
\text { dose } 2-1 \mu \mathrm{g} \text { (on } \\
\text { haemodialysis patients up } \\
\text { to } 20 \mu \mathrm{g} \text { ) }\end{array}$ & $\begin{array}{l}\text { Seroprotection rates were significantly lower after } \\
\text { ID immunisation with a dose of I-2 } \mu \text { g compared to } \\
\text { IM immunisation with the standard dose of } 10 \text { or } 20 \\
\mu \mathrm{g} \text {. When an ID dose }>2 \mu \mathrm{g} \text { was used, } \\
\text { seroprotection rates were found equivalent to those } \\
\text { of IM vaccines. }\end{array}$ \\
\hline $\begin{array}{l}\text { Sangare } \\
2009^{34}\end{array}$ & $\begin{array}{l}\text { Hepatitis } \\
\text { B }\end{array}$ & $\begin{array}{l}\text { Review and } \\
\text { Meta-analysis } \\
\text { (random effects } \\
\text { model) }\end{array}$ & $\begin{array}{l}\text { I3 RCT in } \\
\text { Review } \\
5 \\
\text { Meta-analysis }\end{array}$ & $\begin{array}{l}\text { - intramuscular full dose } \\
20 / 10 \mu g \\
\text { - intradermal one fourth/ } \\
\text { one-fifth/one-tenth dose } \\
5-4-2-1 \mu \mathrm{g}\end{array}$ & $\begin{array}{l}\text { ID hepatitis B vaccinationwas slightly (I4\%) less } \\
\text { likely to achieve seroprotection than IM vaccination }\end{array}$ \\
\hline $\begin{array}{l}\text { Fabrizi } \\
2006^{35}\end{array}$ & $\begin{array}{l}\text { Hepatitis } \\
\text { B }\end{array}$ & $\begin{array}{l}\text { Meta-analysis } \\
\text { (random effects } \\
\text { model) }\end{array}$ & 12 & $\begin{array}{l}\text { - intramuscular full dose } \\
160-120-123-80-60-40 \mu \mathrm{g} \\
\text { - intradermal dose } 160- \\
120-100-80-60-50-40-28.2 \\
\mu \mathrm{g}\end{array}$ & $\begin{array}{l}\text { Dialysis patients show higher seroprotection after } \\
\text { ID than IM vaccination schedules }\end{array}$ \\
\hline $\begin{array}{l}\text { Fabrizi } \\
2010^{36}\end{array}$ & $\begin{array}{l}\text { Hepatitis } \\
\text { B }\end{array}$ & $\begin{array}{l}\text { Meta-analysis } \\
\text { (random effects } \\
\text { model) }\end{array}$ & 14 & $\begin{array}{l}\text { - intramuscular dose } 160- \\
\text { I27-120-80-60-40 } \mu \mathrm{g} \\
\text { - intradermal dose } 120- \\
100-80-70-60-50-40-24-20 \\
\mu \mathrm{g}\end{array}$ & $\begin{array}{l}\text { ID hepatitis B vaccine induces a superior response } \\
\text { rate compared to IM route at completion of vaccine } \\
\text { cycle, despite a lower vaccine dose }\end{array}$ \\
\hline
\end{tabular}

Abbreviations: IM, intramuscular; ID, intradermal.

course. The results suggested that fractional ID doses of the HBV vaccine are more beneficial in hemodialysis patients than in other populations, but these stronger antibody responses could also simply be caused by the high ID doses of the vaccine used in hemodialysis patient studies.

Also Zhang et al in 2015 reported the potentiality of ID vaccination to generate greater immune responses than IM, considering the capability of the dermis to amplify, through local immune cells, the immune responses and the possibility of a consequent vaccine dose sparing. The authors outline that vaccination strategy, vaccine delivery route, instruments used for vaccine delivery, number of, site of, and interval between administrations can influence the efficacy of a vaccine product. These parameters should be taken into account in order to prepare both preclinical and clinical studies to evaluate the efficacy of vaccines. ${ }^{37}$

New technologies are being developed for vaccination against infectious diseases by exploring the capacities of the skin immune system, such as microneedle array patch (MAP), high-density MAP or new skin-targeted drug delivery strategies, and several works have shown encouraging results. ${ }^{38,39}$

Use of dissolvable microneedle patches for influenza vaccination was well-tolerated and generated robust 
antibody responses, ${ }^{40}$ and even a dose reduction $(2.5 \mu \mathrm{g}$ dose $-1 / 6$ of the standard dose) would seem to induce an immunization similar to full dose of $15 \mu \mathrm{g}$ injected $\mathrm{IM}^{41}$ A recent work encourage the improved of MAP delivery strategies for vaccination because of the advantages of less pain, self-administration, improved stability, convenience, and safety. ${ }^{42}$ In this sense the development of new strategies MAP-delivered for vaccines should be useful against emerging infectious diseases, including COVID-19. ${ }^{43}$

At the moment researchers have developed various types of vaccines with the release of the genetic sequence of the SARSCoV-2 virus, and these include inactivated viral vaccines, protein subunit vaccines, mRNA vaccines, and recombinant viral vector vaccines. ${ }^{44}$ Among all the methods of vaccine development, the mRNA vaccines turned out to be the one of the most versatile vaccine with quick responses, ${ }^{45}$ but the identification of the ideal vaccine is still under investigation. Moreover maintaining Research and Development (R\&D) incentives, running clinical trials, authorizations, post-market surveillance, manufacturing and supply, global dissemination, allocation, uptake, and clinical system adaption, remain crucial challenges for decision-makers in the management of the ongoing immunization of the COVID-19 pandemic. ${ }^{46}$

Taking into account these various challenges, and in according with some expert commentary, ${ }^{37}$ we prompt the promotion of studies investigating the effectiveness of ID fractional doses also for COVID 19 vaccines on the basis of data reported from ID fractioning doses of other vaccines used in other diseases. Studies investing the effectiveness of ID fractional dose should be performed for every type of COVID-19 vaccine.

\section{Conclusions}

The use of intradermal vaccines represents a valid strategy in terms of efficacy and efficiency for influenza, rabies and HBV vaccines with doses above $2 \mu \mathrm{g}$, while it still remains doubtful for PV and measles vaccines. Clinical studies of remaining vaccines against other pathogens (HAV, DTP bacterias, JE, meningococcal disease, VZV, and yellow fever virus) are scarce, but in most cases promising. Regarding the safety profile of ID vaccines, they appear to be generally comparable to IM and SC vaccines, although minor local adverse events (erythema and pruritus) appear to be more frequent with the use of ID formulations. A further strong point of ID administration is the potential for rapid achievement of herd immunity (more doses available due to the drug saving effect achieved with the ID route). The Italian Society of Mesotherapy has recently underlined the potential of ID administration, and in particular also in immunoprophylaxis. ${ }^{47-49}$ Assuming the effectiveness of a lower dose of vaccine and, consequently, increasing the availability of doses to vaccinate more people, this appears to be an area of unprecedented scientific urgency. If confirmed by ad hoc studies, could this hypothesis represent a useful strategy deployed against the COVID-19 pandemic? Many people live in countries with very limited economic resources, and one of the ethical challenges will be making the vaccine available to even the poorest countries. The simplicity of administration could also help us achieve herd immunity quickly. We urge the scientific community and health authorities to investigate the potentiality of intradermal route administration.

\section{Disclosure}

The authors report no conflicts of interest in this work.

\section{References}

1. Badgujar KC, Badgujar VC, Badgujar SB. Vaccine development against coronavirus (2003 to present): an overview, recent advances, current scenario, opportunities and challenges. Diabetes Metab Syndr. 2020;14(5):1361-1376. doi:10.1016/j.dsx.2020.07.022

2. Schnyder JL, De Pijper CA, Garcia Garrido HM, et al. Fractional dose of intradermal compared to intramuscular and subcutaneous vaccination - A systematic review and meta-analysis. Travel Med Infect Dis. 2020;37:101868. doi:10.1016/j.tmaid.2020.101868

3. Schaumburg F, De Pijper CA, Grobusch MP. Intradermal travel vaccinations when less means more. Trav Med Infect Dis. 2019;28:3-5.

4. Lambert PH, Laurent P. Intradermal vaccine delivery: will new delivery systems transform vaccine administration? Vaccine. 2008;26:3197-3208.

5. Nicolas J-F, Guy B. Intradermal, epidermal and transcutaneous vaccination: from immunology to clinical practice. Expert Rev Vaccines. 2008;7:1201-1214.

6. World Health Organization and Programme for Appropriate Technology in Health (Path). Intradermal Delivery of Vaccines: A Review of the Literature and the Potential for Development for Use in Low-And Middle-Income Countries. Geneva, Switzerland: World Health Organization; 2009.

7. Hettinga J, Carlisle R. Vaccination into the dermal compartment: techniques, challenges, and prospects. Vaccines (Basel). 2020;8 (3):534. doi:10.3390/vaccines8030534

8. Kupper TS, Fuhlbrigge RC. Immune surveillance in the skin: mechanisms and clinical consequences. Nat Rev Immunol. 2004;4 (3):211-222. doi:10.1038/nri1310

9. Pasparakis M, Haase I, Nestle FO. Mechanisms regulating skin immunity and inflammation. Nat Rev Immunol. 2014;14 (5):289-301. doi:10.1038/nri3646

10. Klicznik MM, Szenes-Nagy AB, Campbell DJ, Gratz IK. Taking the lead - how keratinocytes orchestrate skin T cell immunity. Immunol Lett. 2018;200:43-51. 
11. Dinarello CA. Interleukin-1, interleukin-1 receptors and interleukin-1 receptor antagonist. Int Rev Immunol. 1998;16:457-499. doi:10.3109/ 08830189809043005

12. Matejuk A. Skin immunity. Arch Immunol Ther Exp (Warsz). 2018;66 (1):45-54. doi:10.1007/s00005-017-0477-3

13. Egawa G, Kabashima K. Role of lymphoid structure in skin immunity. Curr Top Microbiol Immunol. 2020;426:65-82. doi:10.1007/82_2020_206

14. Zehrung D, Jarrahian C, Wales A. Intradermal delivery for vaccine dose sparing: overview of current issues. Vaccine. 2013;31:3392-3395. doi:10.1016/j.vaccine.2012.11.021

15. McElhaney JE, Dutz JP. Better influenza vaccines for older people: what will it take? J Infect Dis. 2008;198(5):632-634. doi:10.1086/ 590435

16. Young F, Marra F. A systematic review of intradermal influenza vaccines. Vaccine. 2011;29(48):8788-8801. doi:10.1016/j. vaccine.2011.09.077

17. Song JY, Cheong HJ, Noh JY, et al. Long-term immunogenicity of the influenza vaccine at reduced intradermal and full intramuscular doses among healthy young adults. Clin Exp Vaccine Res. 2013;2 (2):115-119. doi:10.7774/cevr.2013.2.2.115

18. Hung IFN, Yuen KY. Immunogenicity, safety and tolerability of intradermal influenza vaccines. Human Vaccine Immunother. 2018;14(3):565-570. doi:10.1080/21645515.2017.1328332

19. Anand A, Molodecky NA, Pallansch MA, Sutter RW. Immunogenicity to poliovirus type 2 following two doses of fractional intradermal inactivated poliovirus vaccine: a novel dose sparing immunization schedule. Vaccine. 2017;35(22):2993-2998. doi:10.1016/j.vaccine.2017.03.008

20. Resik S, Tejeda A, Lago PM, et al. Randomized controlled clinical trial of fractional doses of inactivated poliovirus vaccine administered intradermally by needle-free device in Cuba. $J$ Infect Dis. 2010;201:1344-1352. doi:10.1086/651611

21. Anand A, Zaman K, Estivariz CF, et al. Early priming with inactivated poliovirus vaccine (IPV) and intradermal fractional dose IPV administered by a microneedle device: a randomized controlled trial. Vaccine. 2015;33:6816-6822. doi:10.1016/j.vaccine.2015.09.039

22. Mohammed AJ, AlAwaidy S, Bawikar S, et al. Fractional doses of inactivated poliovirus vaccine in Oman. $N$ Engl J Med. 2010;362:2351-2359. doi:10.1056/NEJMoa0909383

23. Resik S, Tejeda A, Sutter RW, et al. Priming after a fractional dose of inactivated poliovirus vaccine. $N$ Engl J Med. 2013;368:416-424. doi:10.1056/NEJMoa1202541

24. Sutter RW, Bahl S, Deshpande JM, et al. Immunogenicity of a new routine vaccination schedule for global poliomyelitis prevention: an open-label, randomised controlled trial. Lancet. 2015;386:2413-2421. doi:10.1016/S0140-6736(15)00237-8

25. Asturias EJ, Bandyopadhyay AS, Self S, et al. Humoral and intestinal immunity induced by new schedules of bivalent oral poliovirus vaccine and one or two doses of inactivated poliovirus vaccine in Latin American infants: an open-label randomised controlled trial. Lancet. 2016;388:158-169. doi:10.1016/S0140-6736(16)00703-0

26. Saez-Llorens X, Clemens R, Leroux-Roels G, et al. Immunogenicity and safety of a novel monovalent high-dose inactivated poliovirus type 2 vaccine in infants: a comparative, observer-blind, randomised, controlled trial. Lancet Infect Dis. 2016;16:321-330. doi:10.1016/ S1473-3099(15)00488-0

27. World Health Organization. Summary of the April 2016 Meeting of the Strategic Advisory Group of Experts on Immunization (SAGE). Switzerland, Geneva: World Health Organization; 2016:1-4.

28. Denis M, Knezevic I, Wilde H, Hemachudha T, Briggs D, Knopf L. An overview of the immunogenicity and effectiveness of current human rabies vaccines administered by intradermal route. Vaccine. 2019;37:A99-A106. doi:10.1016/j.vaccine.2018.11.072
29. Egunsola O, Clement F, Taplin J, et al. Immunogenicity and safety of reduced-dose intradermal vs intramuscular influenza vaccines. A systematic review and meta-analysis. JAMA Netw Open. 2021;4 (2):e2035693. doi:10.1001/jamanetworkopen.2020.35693

30. Marra F, Young F, Richardson K, Marra CA. A meta-analysis of intradermal versus intramuscular influenza vaccines: immunogenicity and adverse events. Influ Other Respir Viruses. 2013;7:584-603. doi:10.1111/irv. 12000

31. Pileggi C, Mascaro V, Bianco A, Nobile CG, Pavia M. Immunogenicity and safety of intradermal influenza vaccine in the elderly: a meta-analysis of randomized controlled trials. Drugs Aging. 2015;32:857-869. doi:10.1007/s40266-015-0303-8

32. Pileggi C, Lotito F, Bianco A, Nobile CG, Pavia M. Immunogenicity and safety of intradermal influenza vaccine in immunocompromized patients: a meta-analysis of randomized controlled trials. BMC Infect Dis. 2015;15:427. doi:10.1186/s12879-015-1161-z

33. Langedijk AC, De Pijper CA, Spijker R, Holman R, Grobusch MP, Stijnis C. Rabies antibody response after booster immunization: a systematic review and meta-analysis. Clin Infect Dis. 2018;67:1932-1947. doi:10.1093/cid/ciy420

34. Sangare L, Manhart L, Zehrung D, Wang CC. Intradermal hepatitis $B$ vaccination: a systematic review and meta-analysis. Vaccine. 2009;27:1777-1786. doi:10.1016/j.vaccine.2009.01.043

35. Fabrizi F, NDixit V, Magnini M, Elli A, Martin P. Meta-analysis: intradermal vs. intramuscular vaccination against hepatitis B virus in patients with chronic kidney disease. Aliment Pharmacol Ther. 2006;24:497-506. doi:10.1111/j.1365-2036.2006.03002.x

36. Fabrizi F, Dixit V, Messa P, Martin P. Intradermal vs intramuscular vaccine against hepatitis $B$ infection in dialysis patients: a meta-analysis of randomized trials. $J$ Viral Hepat. 2011;18 (10):730-737. doi:10.1111/j.1365-2893.2010.01354.x

37. Zhang L, Wang W, Wang S. Effect of vaccine administration modality on immunogenicity and efficacy. Expert Rev Vaccines. 2015;14 (11):1509-1523. doi:10.1586/14760584.2015.1081067

38. Kazuhiko M, Sachiko H, Naoki O, Shinsaku N. Frontiers of transcutaneous vaccination systems: novel technologies and devices for vaccine delivery. Vaccine. 2013;31(19):2403-2415.

39. Hossain MK, Ahmed T, Bhusal P, et al. Microneedle systems for vaccine delivery: the story so far. Expert Rev Vaccines. 2020;19 (12):1153-1166. doi:10.1080/14760584.2020.1874928

40. Rouphael NG, Paine M, Mosley R, et al. The safety, immunogenicity, and acceptability of inactivated influenza vaccine delivered by microneedle patch (TIV-MNP 2015): a randomised, partly blinded, placebo-controlled, Phase 1 trial. Lancet. 2017;390 (10095):649-658. doi:10.1016/S0140-6736(17)30575-5

41. Forster AH, Witham K, Depelsenaire AC, et al. Safety, tolerability, and immunogenicity of influenza vaccination with a high-density microarray patch: results from a randomized, controlled Phase I clinical trial. PLoS Med. 2020;17(3):e1003024. doi:10.1371/journal.pmed.1003024

42. Nguyen TT, Oh Y, Kim Y, Shin Y, Baek SK, Park JH. Progress in microneedle array patch (MAP) for vaccine delivery. Human Vaccines Immunother. 2020;1-12.

43. Korkmaz E, Balmert SC, Sumpter TL, Carey CD, Erdos G, Falo LD. Microarray patches enable the development of skin-targeted vaccines against COVID-19. Adv Drug Deliv Rev. 2021;171:164-186.

44. Loo KY, Letchumanan V, Ser HL, et al. COVID-19: insights into potential vaccines. Microorganisms. 2021;9(3):605. doi:10.3390/ microorganisms9030605

45. Talukder P, Chanda S. RNAi technology and investigation on possible vaccines to combat SARS-CoV-2 infection. Appl Biochem Biotechnol. 2021;7:1-13.

46. Forman R, Shah S, Jeurissen P, Jit M, Mossialos E. COVID-19 vaccine challenges: what have we learned so far and what remains to be done? Health Policy (New York). 2021;125:553-567. doi:10.1016/j.healthpol.2021.03.013 
47. Mammucari M, Russo D, Maggiori E, et al. Expert panel. Evidence based recommendations on mesotherapy: an update from the Italian society of Mesotherapy. Clin Ther. 2021;171(1):e37-e45.

48. Mammucari M, Vellucci R, Mediati DR, et al. What is mesotherapy? Recommendations from an international consensus. Trends Med. 2014;14:1-10.
49. Mammucari M, Gatti A, Maggiori S, et al. Mesotherapy, definition, rationale and clinical role: a consensus report from the Italian Society of Mesotherapy. Eur Rev Med Pharmacol Sci. 2011;15:682-694.

\section{Publish your work in this journal}

Risk Management and Healthcare Policy is an international, peerreviewed, open access journal focusing on all aspects of public health, policy, and preventative measures to promote good health and improve morbidity and mortality in the population. The journal welcomes submitted papers covering original research, basic science, clinical \& epidemiological studies, reviews and evaluations, guidelines, expert opinion and commentary, case reports and extended reports. The manuscript management system is completely online and includes a very quick and fair peer-review system, which is all easy to use. Visit http://www.dovepress.com/testimonials.php to read real quotes from published authors.

Submit your manuscript here: https://www.dovepress.com/risk-management-and-healthcare-policy-journal 